\title{
US government scientists test limits of conflict rules
}

\section{Policy change has made it easier to serve on boards of scientific societies.}

\section{BY EUGENIE SAMUEL REICH}

$\mathrm{W}$ hen Mike McPhaden was elected president of the American Geophysical Union (AGU) last year, he was delighted - but he wasn't sure he would be able to take up the position. McPhaden is an oceanographer at the Pacific Marine Environmental Laboratory in Seattle, Washington, which is run by the National Oceanic and Atmospheric Administration (NOAA). Lawyers at the Department of Commerce, which oversees NOAA, were concerned that leading a scientific organization that lobbies the government on funding and policy matters would create a conflict of interest for McPhaden. "There was resistance," he says.

In the end, McPhaden convinced the agency that taking up the position would bring prestige to his government role and enhance the credibility of NOAA science. Today, a memorandum of understanding between the AGU and NOAA even allows him to spend some of his government-paid time working for the scientific society, although he has to recuse himself from both fund-raising and lobbying.

Now, changes in US government policy should make it much easier for government scientists to serve in scientific societies. A memorandum on scientific integrity issued by the Office of Science and Technology Policy (OSTP) in December explicitly encourages government scientists to get involved with societies; previously, the government tended to view such associations ambivalently or negatively. Yet many government scientists affected by the policy change say that serious legal and ethical pitfalls remain.

Unlike in countries such as Britain, which has no rule against government scientists serving on society boards, the strict conflictof-interest rules in the United States can create administrative barriers for government scientists trying to participate in societies that $\rightarrow$ NATURE.COM For more on the OSTP guidance, see go.nature.com/ter5uj matters in which they or organizations they are associated with have a financial interest. In some cases, the restrictions have been interpreted as preventing government employees from lobbying. Employees who join outside organizations will have to be careful not to run afoul of these rules, notes John Fitzgerald, policy director of the Society for Conservation Biology in Washington DC. Fitzgerald supports the more permissive policy but cautions that a government scientist who lobbies Congress could be "skating on thin ice".

A scientist who has navigated that issue turned down the offer. The Fish and Wildlife Service gives the society a few thousand dollars each year to spend on scientific meetings. She was worried that some might think she got the prestigious board position in exchange for ensuring that the funding continued, and her colleagues shared her concerns. "At the end of the day it's about credibility," she says.

\section{DIFFERENT EMPHASIS}

The US Geological Survey (USGS) has a more liberal approach. USGS scientists are encouraged to serve in scientific societies, and 91 currently do so. Their promotional prospects depend on them showing leadership in the research community - which they can do by being elected to a society board. However, USGS director Marcia McNutt says that conflicts of interest are less likely to arise at the USGS because the agency has no policy-making authority.

Both the Fish and Wildlife Service and the USGS are run by the US Department of the Interior (DOI), and $\mathrm{McNutt}$ is pleased that the department has now consolidated its scientific-integrity policy. The new policy, introduced on 1 February, follows the OSTP guidance and explicitly encourages all researchers within is William Talman, president of the Federation of American Societies for Experimental Biology in Washington DC, who also works as a physician at a hospital in Iowa City run by the US government's Department of Veterans Affairs. Acting as president of the federation, Talman has written to senators to advocate for generous funding for the National Institutes of Health and testified in Congress in support of budget boosts for the US National Science Foundation. Talman says that he takes unpaid leave from his government job for those activities, an arrangement that happens to fit with the new policy. As a result, he says, "I would argue there's no conflict of interest."

Biologist Gabriela Chavarria, who is science adviser to the director of the US Fish and Wildlife Service, worried about a different issue when the Society for Conservation Biology invited her to serve on its board earlier this month. Following discussions with the agency, Chavarria are relevant to their disciplines. Under US law, for example, government officials are barred from participating in he DOI's jurisdiction to participate in scientific societies, although they need to fill out forms before going ahead. That paperwork helps to ensure that researchers understand what kinds of behaviour could be considered a conflict for example, serving on the board of a society and then signing a government purchase order for the society's publications. "Scientists can be clueless about the trouble they can get themselves into," says McNutt.

Various other agencies are now expected to work the OSTP guidance into their policies, and watchdog groups are delighted at the changing attitude. Jeff Ruch, executive director of Public Employees for Environmental Responsibility in Washington DC, says that government lawyers have long been allowed to participate in professional organizations such as the American Bar Association, and says he doesn't see why the practice shouldn't be extended to scientists. 